\title{
Quantification of sucrose in the root of Geum iranicum Khatamsaz
}

\author{
Somayeh Shahani ${ }^{1 *}$, Ahmad Reza Gohari ${ }^{2}$, Hamid Reza Monsef-Esfahani ${ }^{3}$ \\ ${ }^{1}$ Department of Pharmacognosy and Biotechnology, Faculty of Pharmacy, Mazandaran University of Medical Sciences, Sari, Iran \\ ${ }^{2}$ Medicinal Plants Research Center, Tehran University of Medical Sciences, Tehran, Iran \\ ${ }^{3}$ Department of Pharmacognosy, Faculty of Pharmacy, Tehran University of Medical Sciences, Tehran, Iran
}

\begin{abstract}
Geum iranicum Khatamsaz (Rosaceae) is an endemic plant in Iran. The infusion and decoction of the plant have been used by local people for medicinal purposes. Our previous work on phytochemical studies on G. iranicum showed that the root was rich in sugars and sucrose was identified as a major one in it. In this study, the content of sucrose in the hydro-alcoholic (1:1) extract of the root of $G$. iranicum was analyzed using HPLC. The amount of sucrose has been evaluated as $31.75 \%$ in the extract and $8.16 \%$ in the dried root. As a result, the presence of high amount of sucrose in the root of $G$. iranicum can be applicable for preparation of any pharmaceutical formulations of this plant.
\end{abstract}

Keywords: Geum iranicum, root, sucrose, quantification, HPLC

Pharm Biomed Res 2015; 1(3): 31-36

DOI: 10.18869/acadpub.pbr.1.3.31

\section{Introduction}

Geum iranicum is an endemic rhizomatous herb in Iran that belongs to the Rosaceae family $(1,2)$. In Iranian folk remedy, infusion and decoction of the root of this plant are employed for gastrointestinal disorders like diarrhea and by mixing with flour as a poultice for frost bite (3). Few biological and phytochemical studies have been carried out on Geum species in Iran. Our previous work on phytochemical analysis of $G$. iranicum using column chromatography showed that the root was rich in sugars and sucrose was identified as a major sugar in this plant (4). Sugars as primary messengers in signal transduction regulate many important processes along the whole life

cycle of the plant (5). Sucrose is the most abundant disaccharide and the major transported sugar in plants (6). Based on previous studies, the role of sucrose as a signaling molecule in plants has been accepted. Sucrose plays an important role in the regulation of some metabolic processes which its role cannot be replaced by other sugars like glucose and also takes part in a wide range of developmental processes (7). In a research, sugars especially sucrose induced the accumulation of anthocyanins and glucosinolates in broccoli sprouts. The genes involved in the biosynthesis and transcriptional regulation of these compounds were upregulated after the sucrose treatment (8). 
The sucrose content of soybean seeds has an important role to improve the flavor and aroma of soy-based products. For this reason, Teixeira et al developed the simple spectrophotometric method to quantify sucrose in soybean grains (9). Several studies reported the pain reducing effect of oral sucrose in neonates (10). Since the infusion and decoction of $G$. iranicum have been used by local people, this work concentrates to quantification of sucrose as one of the major carbohydrates in this plant using HPLC method for the first time.

\section{Materials and methods \\ Plant material}

G. iranicum was collected from GloulSarani protected area $75 \mathrm{~km}$ north of Shirvan, Khorasan-e- Shomali province, Iran, at an altitude $2460 \mathrm{~m}$. The voucher specimen (6714 THE) was deposited at the Herbarium of the Faculty of Pharmacy, Tehran University of Medical Sciences, Tehran, Iran.

\section{Chemicals}

Purified sucrose from the root of this plant in our previous work (4) was used as standard material. All solvents were obtained from Merck (Germany).

\section{Instrumentation}

HPLC analysis was performed on a Knauer Wellchrom system connected to a photodiode array detector (smart line system, Germany) with the detection wavelength set at $246 \mathrm{~nm}$. The samples were applied to an RP-C18 silica gel column eluted with deionized water and methanol.

\section{Preparation of standard solutions}

Stock solution $(20 \mathrm{mg} / \mathrm{ml})$ of sucrose was prepared in $\mathrm{H}_{2} \mathrm{O}$. Different concentrations $(4,2,1,0.5 \mathrm{mg} / \mathrm{ml})$ were made from stock solution to plot the calibration curve of sucrose.

\section{Sample preparation}

Dried roots of $G$. iranicum (50 g) were cut into small pieces and extracted by soxhlet extracter with methanol-water (1:1) for 4 h. $20 \mathrm{mg}$ of dried extract added to volumetric flask and diluted to $5 \mathrm{ml}$ with methanol-water $(2.5: 2.5)$ (4 $\mathrm{mg} / \mathrm{ml})$. The sample was injected (20 $\mu \mathrm{l})$ to HPLC with a gradient program that is shown in Table 1.

Table1 HPLC elution condition of hydroalcoholic extract of $G$. iranicum

\begin{tabular}{cccc}
\hline Time $(\mathrm{min})$ & Flow $(\mathrm{ml} / \mathrm{min})$ & Water \% & Methanol \% \\
\hline 0 & 1 & 80 & 20 \\
\hline 5 & 1 & 80 & 20 \\
\hline 35 & 1 & 0 & 100 \\
\hline 40 & 1 & 0 & 100 \\
\hline 41 & 1 & 80 & 20 \\
\hline 45 & 1 & 80 & 20
\end{tabular}

\section{Results}

In this study, the purified sucrose $(\mathrm{O}-\alpha-$ D-glucopyranosyl- $(1 \rightarrow 2)-\beta$-Dfructofuranoside, Fig.1) from the root of G. iranicum was used as standard sucrose. The NMR data were as follows: ${ }^{1} \mathrm{H}-\mathrm{NMR}\left(\mathrm{D}_{2} \mathrm{O}, 500 \mathrm{MHz}\right)$ : $\delta_{\mathrm{H}}=3.31\left(1 \mathrm{H}, \mathrm{t}, \mathrm{J}=9.5 \mathrm{~Hz}, \mathrm{H}_{\mathrm{Glc}}-4\right), 3.4$ $\left(1 \mathrm{H}, \mathrm{dd}, \mathrm{J}=10,3.8 \mathrm{~Hz}, \mathrm{H}_{\mathrm{Glc}}-2\right), 3.51$ (2 $\left.\mathrm{H}, \mathrm{s}, \mathrm{H}_{\mathrm{Fru}}-1\right), 3.59(1 \mathrm{H}, \mathrm{t}, \mathrm{J}=9.5 \mathrm{~Hz}$, $\left.\mathrm{H}_{\mathrm{Glc}}-3\right), 3.66$ (4H, m, $\mathrm{H}_{\mathrm{Glc}}-6$ and $\left.\mathrm{H}_{\mathrm{Fru}}-6\right)$, $3.69\left(1 \mathrm{H}, \mathrm{m}, \mathrm{H}_{\mathrm{Glc}}-5\right), 3.72(1 \mathrm{H}, \mathrm{m}$, $\left.\mathrm{H}_{\mathrm{Fru}}-5\right), 3.89\left(1 \mathrm{H}, \mathrm{t}, \mathrm{J}=8.5 \mathrm{~Hz}, \mathrm{H}_{\mathrm{Fru}}-4\right)$, $4.04\left(1 \mathrm{H}, \mathrm{d}, \mathrm{J}=8.7 \mathrm{~Hz}, \mathrm{H}_{\mathrm{Fru}}-3\right), 5.25$ 


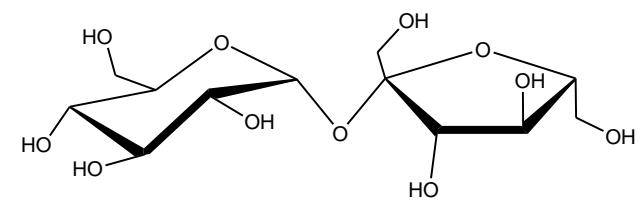

Figure 1 The structure of sucrose

$\left(1 \mathrm{H}, \mathrm{d}, \mathrm{J}=3.8 \mathrm{~Hz}, \mathrm{H}_{\mathrm{Glc}}-1\right) \cdot{ }^{13} \mathrm{C}-\mathrm{NMR}$ $\left(\mathrm{D}_{2} \mathrm{O}, 500 \mathrm{MHz}\right): \delta_{\mathrm{C}}=60.1\left(\mathrm{C}_{\mathrm{Glc}}-6\right)$, $61.3\left(\mathrm{C}_{\mathrm{Fru}}-1\right), 62.3\left(\mathrm{C}_{\mathrm{Fru}}-6\right), 69.2\left(\mathrm{C}_{\mathrm{Glc}^{-}}\right.$ 4), $71.0\left(\mathrm{C}_{\mathrm{Glc}}-2\right), 72.4\left(\mathrm{C}_{\mathrm{Glc}}-5\right), 72.5$ $\left(\mathrm{C}_{\mathrm{Glc}}-3\right), 73.9\left(\mathrm{C}_{\mathrm{Fru}}-4\right), 76.3\left(\mathrm{C}_{\mathrm{Fru}}-3\right)$, $81.3\left(\mathrm{C}_{\mathrm{Fru}}-5\right), 92.1\left(\mathrm{C}_{\mathrm{Glc}^{-}}-1\right), 103.6\left(\mathrm{C}_{\mathrm{Fru}^{-}}{ }^{-}\right.$ 2) (4). The content of sucrose in the hydro-alcoholic (1:1) extract of the root of $G$. iranicum was analyzed using HPLC. Four dilutions of the standard, purified sucrose from the same plant were used for plotting a calibration curve (Fig.2). In this study, a gradient elution of methanol-water was used to achieve complete separation of sucrose in the extract. Purity of sucrose peak in HPLC chromatograms was confirmed with photodiode array detector. Sucrose was identified in the chromatogram of the extract by comparing the UV spectra with those of the standard (Fig.3).
The amount of sucrose has been evaluated as $31.75 \%$ in the extract and $8.16 \%$ in the dried root.

\section{Discussion}

Sorbitol and sucrose are the two main translocatable carbon forms in the Rosaceae family (11). Sorbitol normally occurs in all subfamilies of the Rosaceae, except rosoideae (12). Since the genus Geum belongs to rosoideae (13), our results confirmed the presence of high levels of sucrose in G. iranicum. In folk medicine the root of Geum is employed as a tonic $(14,15)$. It seems that the significant amount of sucrose in the root is one of the important factors that cause this effect. Sucrose is a pharmaceutical excipient which widely used in oral formulations. It is used as a binding, bulking, suspending and coating agents and also sweetener (16). Furthermore, Sucrose is considered for its bacteriostatic, bactericidal and wound healing properties $(17,18)$. Sugar cane and sugar beet plants contain 15$20 \%$ and $10-17 \%$ sucrose respectively (16). Based on our findings, the amount of sucrose in the root of $G$. iranicum was $8.16 \%$ in the dried root which

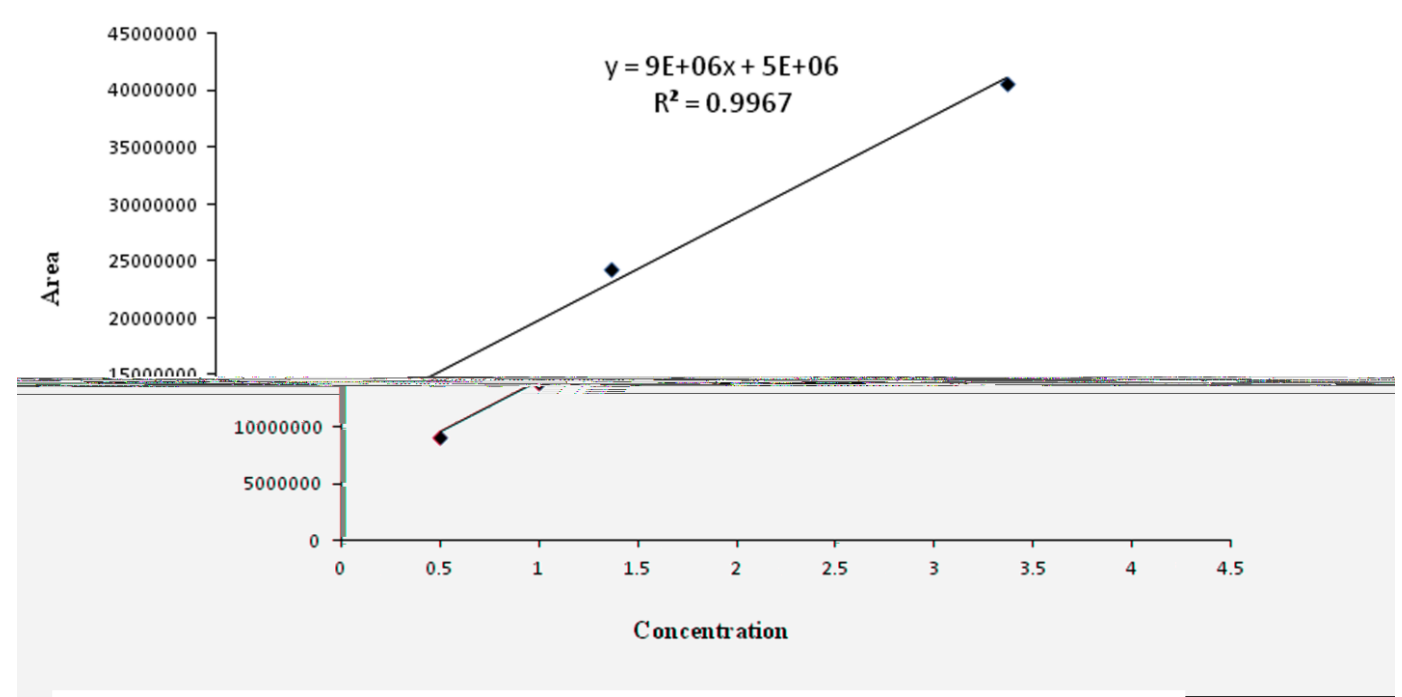

Figure 2 Calibration curve for standard sucrose (concentration vs. peak area) 


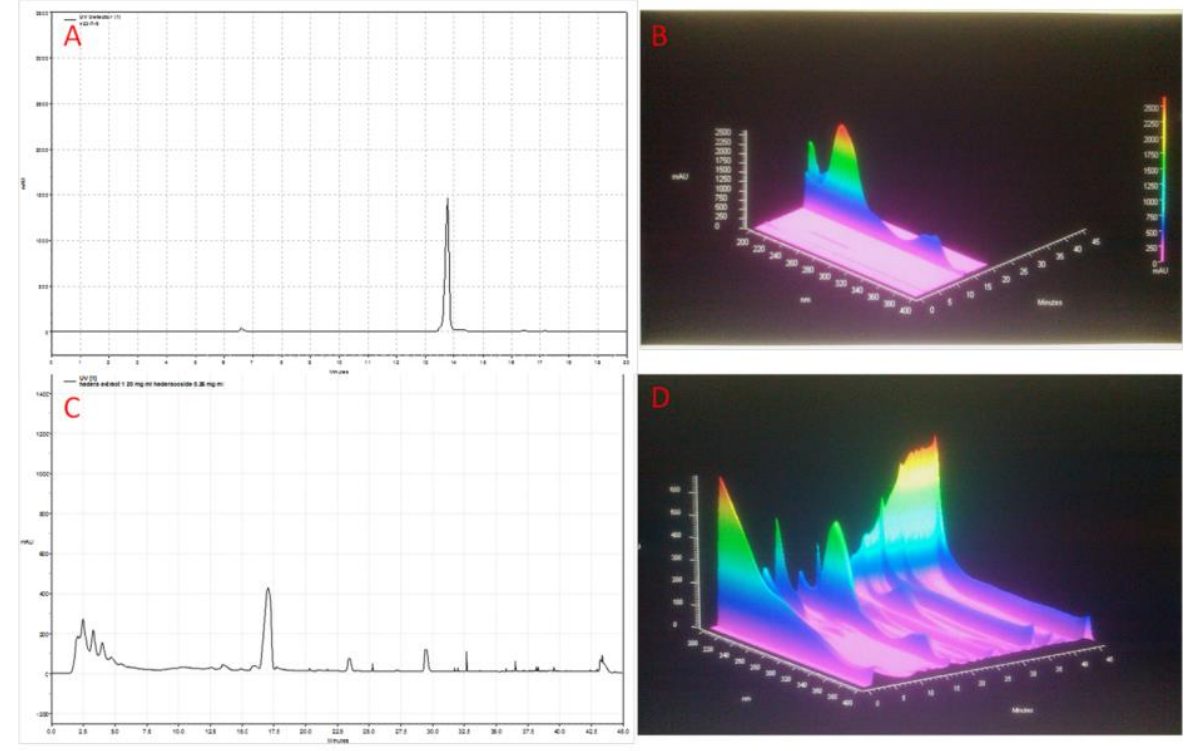

Figure 3 HPLC profiles of sucrose and the hydroalcoholic extract of G. iranicum A: HPLC chromatogram of standard sucrose, B: UV spectrum of sucrose, C: HPLC chromatogram of the extract, D: UV spectrum of the extract

was considerable. Some Geum species like G. rivale, G. urbanum and $G$. japonicum have long been used in folk medicine as a diuretic and astringent $(19,20)$. Recently, much attention has been paid to the Geum genus for their multifaceted activities (21).

Previous studies on Geum species have shown various biological effects such as antioxidant, antimicrobial and antiinflammatory activities $(15,22,23)$. Literature review revealed several studies on G. japonicum which is native in East Asia. Anti viral activity against human immunodeficiency virus (HIV), herpes simplex virus (HSV) and cytomegalo virus (CMV) and also anticoagulant activity have been reported from G. japonicum. Furthermore, this plant showed potent effect on angiogenesis and cardiomyogenesis in acute myocardial infarction in an animal model (24-28). There are five species of the genus Geum in Iran (1). Few studies have been conducted on this genus in our country. In a research the extract and essential oil of $G$. kokanicum showed antimicrobial activity and in another study a potent inhibitory effect on matrix metalloproteinase activity was reported from this plant $(29,30)$. In our previous works we reported the presence of terpenoid, steroid, phenylpropanoid, tannin and sugar in the extract and high amount of eugenol in the essential oil of the roots of $G$. iranicum (4,31). In addition, the aqueous fraction obtained from the root extract of G. iranicum showed a potent antibacterial activity against resistant clinical isolates of Helicobacter pylori (4). Osato et al reported that the osmotic effect of honey's sugar content was the most important factor for observed anti $H$. pylori activity (32). For this reason, it seems that the high amount of sugar in the root of $G$. iranicum might be one of the important compounds responsible for the antibacterial activity. 


\section{Conclusion}

As mentioned above, sucrose is a pharmaceutical excipient and antibacterial, wound healing and pain reducing effects have been reported from this compound. Also it can improve the flavor and aroma of any products. As a result, the presence of sucrose in high levels in the root of $G$. iranicum can be applicable for preparation of any pharmaceutical formulations of this plant.

\section{Acknowledgement}

This research has been supported by a grant from Tehran University of Medical

\section{References}

1. Mozaffarian V. A Dictionary of Iranian plant names. Tehran: Farhang Moaser Publication; 1996. p. 246.

2. Khatamsaz K. Flora of Iran, No. 6: Rosaceae. Karaj: Research Institute of Forest and Rangelands; 1992. p. 84-5.

3. Abutorabi H. Ethnobotanical and phytochemical study on the plants of Rouin region. Pharm. D. Thesis. Faculty of Pharmacy, Tehran University of Medical Sciences, Tehran, Iran; 2001. p. 134.

4. Shahani S, Monsef-Esfahani HR, Saeidnia S, Saniee P, Siavoshi F, Foroumadi A, et al. Anti-Helicobacter pylori activity of the methanolic extract of Geum iranicum and its main compounds. Z Naturforsch C 2012;67:172-80.

5. Rolland F, Moore B, Sheen J. Sugar sensing and signaling in plants. Plant Cell 2002;14:185-205.

6. Halford NG, Curtis TY, Muttucumaru N, Postles J, Mottram DS. Sugars in crop plants. Ann Appl Biol 2011;158:1-25.

7. Tognetti JA, Pontis HG, Martínez-Noël GM. Sucrose signaling in plants: a world yet to be explored. Plant Signal Behav 2013;8:e23316.

8. Guo R, Yuan G, Wang Q. Sucrose enhances the accumulation of anthocyanins and glucosinolates in broccoli sprouts. Food Chem 2011;129:1080-7.

Sciences. The authors thank Mr. Yousef Ajani from the Institute of Medicinal Plants (Jahade-Daneshgahi) for plant collection and identification.

\section{Conflict of interest}

The authors declared no potential conflict of interest with respect to the authorship, and/or publication of this study.
9. Teixeira AL, Ribeiro LF, Rezende ST, Barros EG, Moreira MA. Development of a method to quantify sucrose in soybean grains. Food Chem 2012;130:1134-6.

10. Campbell N, Cleaver K, Davies N. Oral sucrose as analgesia for neonates: How effective and safe in the sweet solution? A review of the literature. J Neonatal Nurs 2014;20:274-82.

11. Marino G, Bertazza G, Magnanini E, Altan AD. Comparative effects of sorbitol and sucrose as main carbon energy sources in micropropagation of apricot, Plant Cell Tissue Organ Cult 1993;34:235-44.

12. Rønsted N, Bello MA, Jensen SR. Aragoside and iridoid glucosides from Aragoa cundinamarcensis. Phytochemistry 2003;64:529-33.

13. Lamaison JL, Carnat A, Petitjean-Freytet C. Tannin content and inhibitory activity elastase in Rosaceae. Ann Pharm Fr 1990;48:335-40.

14. Zargari A. Medicinal plants, Vol.2. 5th ed. Tehran University Publications; 1991. p. 172.

15. Panizzi L, Catalano S, Miarelli C, Cioni PL, Campeol E. In vitro antimicrobial activity of extracts and isolated constituents of Geum rivale. Phytother Res 2000;14:561-3.

16. Rowe RC, Sheskey PJ, Cook WG, Fenton ME, editors. Handbook of pharmaceutical 
excipients, 7th ed. Pharmaceutical Press; 2012. p.807.

17. Vizcaíno CM, Alarcón AI, Sebazco PC, Maceira CMA. Importance of sucrose for healing infected wounds. Rev Cub Med Mil 2013;42:49-55.

18. Mphande AN, Killowe C, Phalira S, Jones HW, Harrison WJ. Effects of honey and sugar dressings on wound healing, J Wound Care 2007;16:317-9.

19. Gruenwald J, Brendler T, Jaenicke C, editors. PDR for Herbal Medicine. 3rd ed. Montvale: Thomson PDR; 2004.

20. Heo JC, Son M, Woo SU, Kweon MA, Yoon EK, Lee HK, et al. A fraction of methylene chloride from Geum japonicum Thunberg inhibits tumor metastatic and angiogenic potential. Oncol Rep 2008;19:1399-403.

21. Cheng XR, Jin HZ, Qin JJ, Fu JJ, Zhang WD. Chemical constituents of plants from the genus Geum. Chem Biodivers 2011;8:203-22.

22. Russo A, Cardile V, Lombardo L, Vanella A, Garbarino JA. Antioxidant activity and anti proliferative action of methanolic extract of Geum quellyon sweet roots in human tumor cell lines. J Ethnopharmacol 2005;100:323-32.

23. Tunón $\mathrm{H}$, Olavsdotter $\mathrm{C}$, and Bohlin L. Evaluation of anti-inflammatory activity of some Swedish medicinal plants. Inhibition of prostaglandin biosynthesis and PAFinduced exocytosis. J Ethnopharmacol 1995;48:61-76.

24. Xu HX, Ming DS, Dong H, But PPH. A new anti-HIV triterpene from Geum japonicum. Chem Pharm Bull 2000;48:1367-9.

25. Kurokawa M, Nagasaka K, Hirabayashi T, Uyama S, Sato H., Kageyama T, et al. Efficacy of traditional herbal medicines in combination with acyclovir against herpes simplex virus type 1 infection in vitro and in vivo. Antiviral Res 1995;27:19-37.
26. Yukawa TA, Kurokawa $\mathrm{M}$, Sato $\mathrm{H}$, Yoshida Y, Kageyoma S, Hasegawa T, et al. Prophylactic treatment of cytomegalovirus infection with traditional herbs. Antiviral Res 1996;32:63-70.

27. Zeng FQ, Xu HX, Sim KY, Gunsekera RM, Cheu SX. The anticoagulant effects of Geum japonicum extract and its constituents. Phytother Res 1998;12:146-8.

28. Li M, Yu CM, Cheng L, Wang M, Gu X, Lee $\mathrm{KH}$, et al. Repair of infarcted myocardium by an extract of Geum japonicum with dual effects on angiogenesis and myogenesis. Clin Chem 2006;52:1460-8.

29. Faramarzi MA, Moghimi M, MonsefEsfahani HR, Shahverdi AR, and Khodaee S. Chemical composition and antimicrobial activity of essential oils from Geum kokanicum. Chem Nat Compd 2008;44:811-3.

30. Khorramizdeh MR, Shahverdi AR, Saadat F, Monsef-Esfahani HR. Inhibitory effect of Geum kokanicum roots on matrix metalloproteinases expression. Pharm Biol 2006;44:266-70.

31. Shahani S, Monsef-Esfahani HR, Hajiaghaee R, Gohari AR. Chemical composition of essential oil and hydrolat of Geum iranicum Khatamsaz. J Essent Oil Res 2011;23:29-33.

32. Osato MS, Reddy SG, Graham DY. Osmotic effect of honey on growth and viability of Helicobacter pylori. Dig Dis Sci 1999;44:462-4. 